\title{
PHYLOGENETIC RELATIONSHIPS OF SOME PHYTOPATHOGENIC SCLEROTIAL FUNGI INFERRED FROM RIBOSOMAL DNA SEQUENCES AND MORPHOLOGICAL CHARACTERS
}

\author{
GEHLOT PRAVEEN *1, SINGH S.K. ${ }^{2}$ and PATHAK RAKESH ${ }^{2}$ \\ ${ }^{1}$ Department of Botany, Jai Narain Vyas University, Jodhpur; \\ ${ }^{2}$ Central Arid Zone Research Institute, Jodhpur \\ *Corresponding Author: Email- drpg73@rediffmail.com
}

Received: October 22, 2011; Accepted: November 22, 2011

\begin{abstract}
Thirty eight fungal cultures were raised from 24 infected host plant species. These fungal cultures were categorized in to five groups based on their cultural and sclerotial characteristics. Group I, II, III, IV and V included 12, 9, 7, 5 and 5 isolates, respectively. The isolates of group I were identified as $R$. bataticola, group II as M. phaseolina, group III as $R$. solani, group IV as Sclerotium rolfsii and group V as Sclerotinia sclerotiorum. Sequences of internal transcribed spacer (ITS) region with $5.8 \mathrm{~S}$ gene of sclerotial fungi resolved phylogenetic affinities with variable evolutionary rate. Parsimony analysis grouped three species $R$. solani, $R$. bataticola and Sclerotium rolfsii belonging to Basidiomycota together and M. phaseolina and $S$. sclerotiorum belonging to Ascomycota formed a separate group. $R$. solani and $S$. rolfsii were found to have affinities with the teleomorph genera. $R$. solani and $R$. bataticola taxa represent two distinct lineages. $R$. bataticola and M. phaseolina showed the maximum similarity based on ITS 5.8 S gene sequences but INDELS show variation which validate independent evolutionary lineage. Study revealed new insights into phylogenetic relationship of sclerotial species useful in assessing fungicide application strategies for disease management.
\end{abstract}

Keywords- morphology, phylogeny, rDNA-sequencing, sclerotia, fungi

\section{Introduction}

Sclerotial pathogens (Rhizoctonia solani) J.G. Kuhn, Rhizoctonia bataticola (Taubenh.) E.J., Macrophomina phaseolina (Tassi) Goid., Sclerotium rolfsii Sacc. and Sclerotinia sclerotiorum (Lib.) de Bary) are some of the most destructive fungal plant pathogens causing diseases in plants encompassing more than 500 host species belonging to 100 families [1-5]. These plant pathogens cause many diseases like damping off, seeding blight, collar rot, stem rot, foot rot, stem blight, charcoal rot, sclerotium wilt and root rot in various economically important crops. Control efforts have often met with limited success due to extensive host range, prolific growth rate and ability to produce large number of sclerotia that usually remain viable in soil for several years. Furthermore, control measures effective for particular crop in an area may not be adaptable elsewhere due to regulatory or economic constraints. Although, numerous common fungicide have been used to control these destructive plant pathogens based on sclerotial fruiting body (morphological criteria) but due to wide variation in the pathogens, these criteria are not reliable [6]. The management of these pathogens is still a challenge. Moreover these fungi also possess very similar morphological characters resulting in considerable ambiguity and confusion in inter-generic classification. The classification, validity and delimitation of these genera have been problematic. The identification of $R$. bataticola and $M$. phaseolina in culture are usually based on morphological criteria but due to less variation in the cultural characters of these isolates it is often not reliable. However, no such marker is available for specific detection and distinction of $M$. phaseolina and $R$. bataticola. Screening of the Gen bank for the sequences of $M$. phaseolina revealed the existence of very few sequences that showed some degree of variation among them [7]. However information from authentic isolates is required to confirm this.

The interrelationships between these phytopathogens with their phylogenetic analyses is required for diagnostics, taxonomy grouping, marker assisted resistance breeding programs and to distinct lineages intended for development of new policy for effective and individual/ common control measure using pesticides and bio-control agents.

Analysis of Nuclear rDNA genes, particularly in the internal transcribed spacer (ITS) regions is good target for determining inter-species variations and phylogenic analysis of fungal species [8]. The rDNA region contains both variable and conserved regions allowing the comparison and discrimination of organisms at different taxonomic level. The internal transcribed spacers (ITS 1 and ITS 2) of 5.8S rRNA gene evolve relatively quickly and can be useful in determining inter-species variations and phylogenetic evolution. The present study was focused on determining phylogenetic placement of important plant pathogenic sclerotial fungi based on nrDNA sequence data and to trace the phylatic lineages. 


\section{Materials and methods}

Sclerotial pathogens $(R$. solani, $R$. bataticola, $M$. phaseolina, Sclerotium rolfsii and Sclerotinia sclerotiorum) were isolated from infected leaves and infected roots of 24 different host plants from various localities of Jodhpur district of Rajasthan, India and cultured on potato dextrose agar (PDA) media at $25^{\circ} \mathrm{C} \pm$ $2^{\circ} \mathrm{C}$. Growing mycelium tips were sub-cultured for purification of cultures. The colonies developed within 34 days and sclerotial formation started within a week. The colony morphology i.e. colour, growth rate, texture, mycelium form and other characters related to morphological identification of each isolate were recorded.

The genomic DNA was extracted from fresh cultures grown on malt extract glucose broth culture medium. Approximately $100 \mathrm{mg}$ of each fungal mycelium was crushed with a micro-pestle in conical $1.5 \mathrm{ml}$ micro centrifuge tube with liquid nitrogen. DNeasy ${ }^{\circledR}$ plant minikit protocols of Qiagen GMBH (Germany) were used for DNA isolation. The quality of DNA was checked on $0.8 \%$ (wt/vol) agarose in a gel electrophoresis with $1 \times$ TAE buffer and analyzed after staining with ethidium bromide. The purity of the extracted DNA was checked at $260 \mathrm{~nm}$ and $280 \mathrm{~nm}$ (Pharma Spec UV-1700, Shimadzu Company).The universal primers ITS-1 (19bp) and ITS-4 (20bp) were used to amplify the ITS-I and ITSII regions of ribosomal DNA, which encompasses the 5.8S rRNA gene [9]. Each amplification was performed using PCR in a total volume of $50 \mu$ l containing $0.2 \mu \mathrm{l}$

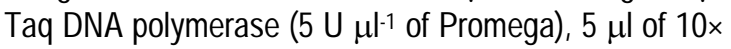
PCR buffer (10 mM Tris HCl, pH 8.3, $500 \mathrm{mM} \mathrm{KCl,} 15$ $\mathrm{mM} \mathrm{MgCl}$, Sigma Chem) $0.4 \mu \mathrm{l}$ dNTP mix $2.0 \mathrm{mM}$ each A,T,C,G (MBI, Fermentas), $1 \mu$ of each ITS-1and ITS-4 primers, $2 \mu \mathrm{l}$ of $5 \%$ (vol/vol) glycerol, $4 \mu \mathrm{l}$ of genomic DNA and $36.4 \mu \mathrm{ld} \mathrm{H}_{2} \mathrm{O}$. The reactions were performed in a gradient thermal cycler (Corbett Research, USA) with following conditions i.e. 1-min denaturation at $95^{\circ} \mathrm{C}, 30$ $\mathrm{s}$ annealing at $50{ }^{\circ} \mathrm{C}$, 1-min 20 -s elongation at $72{ }^{\circ} \mathrm{C}$, repetition 34-times with a final elongation step of 10-min at $72^{\circ} \mathrm{C}$.

The PCR products were visualized on $1.5 \%$ (wt/vol) Agarose gel in Tris-acetic acid EDTA ( $1 \times$ TAE) buffer at $60-V$ for 100- min. Agarose gel was stained with ethidium bromide and photographed under UV light using Syngene gel documentation system. Each amplified PCR product of ITS amplified region containing ITS1, 5.8S rRNA gene and ITS2 was directly sequenced using ITS-1 (forward primer) and ITS-4 (reverse primer) by big dye terminator method on $A B I$ prism DNA sequencer. The sequence data obtained from ITS-4 reverse primer was inversed using Genedoc software and clubbed with sequence data of ITS-1 after deleting the common portions to obtain complete sequence of amplified ITS product. Nucleotide sequence comparisons were performed by using Basic Local Alignment Search Tool (BLAST) network services of the National Centre for Biotechnology Information (NCBI) database. The fungal species were designated to the sequenced analyses based on similarity with the best aligned sequence of
BLAST search. Multiple 5.8S rRNA gene alignment was performed using clustal $X 1.83$ software. The complete rDNA sequences of ITS1 and ITS2 encompassing 5.8S of different species were submitted to NCBI database and Gen Accession numbers obtained. The phylogenetic relationships of different species were established by generating phylogram using tree view software based on single nucleotide polymorphisms in the ITS region of 5.8S ribosomal DNA gene.

\section{Results}

In all 38 fungal cultures were raised out of 24 infected host plant species. These fungal cultures were broadly categorized in to five groups based on cultural and sclerotial characteristics. Group I, II, III, IV and V included 12, 9, 7, 5 and 5 isolates, respectively. The genomic DNA of a representative culture from each group was subjected to PCR for amplification of $5.8 \mathrm{~S}$ rDNA region. The PCR amplified products of the sclerotial pathogens generated a single prominent band on agarose gel (Fig. 1). The DNA sequences were subjected to BLAST hits with NCBI reference sequences. The isolates of group I were identified as $R$. bataticola, group II as M. phaseolina, group III as $R$. solani, group IV as Sclerotium rolfsii and group $\mathrm{V}$ as Sclerotinia sclerotiorum. A representative sequence of each sclerotial species was subjected to multiple sequence alignment for determining taxonomic grouping, phylogenetic affinities and cladistic analyses. The nucleotide base pair lengths of internal transcribed spacer regions encompassing $5.8 \mathrm{~S}$ ribosomal rDNA gene of five species of sclerotial pathogen, cultural characteristics and Gen Accession numbers are presented in Table 1. The amplified product of ITS region (ITS1-5.8S-ITS2) of sclerotial fungi ranged between 452 to $626 \mathrm{bp}$. Interestingly, Rhizoctonia solani was recorded with the maximum gene length of 626 bp which was significantly higher than all other sclerotial pathogens. Gene sequences of all five sclerotial fungi are connected to both Ascomycetes and Basidiomycetes classes based on the maximum identical sequences with the available sequences in the NCBI database. $R$. solani, $R$. bataticola and Sclerotium rolfsii belongs to Basidiomycetes, whereas, M. phaseolina and S. sclerotiorum are members of Ascomycetes. The multiple sequence aligned data was used to generate phylogram (Fig. 2). The phylogram showed that all the sclerotial fungi do not arise from single branch and validated polyphyletic associations. The phylogram showed that all the five species delineated into two clades. Clade 1 included only one species $R$. solani which showed more genetic dissimilarities with other sclerotial pathogens. The clade 2 included four species viz., $S$. sclerotiorum, $R$. bataticola, M. phaseolina and S. rolfsii. However, $S$. rolfsii was found distinctly related to these species of the clade. Subclade 2 was further subdivided into two groups of the species having $R$. bataticola along with $M$. phaseolina and S. sclerotiorum Phylogram showed that $R$. bataticola and $M$. phaseolina are closely related as they cluster together in a single monophyletic clade with 
high boot strap support value even though they belong to different classes of fungi i.e., Basidiomycetes and Ascomycetes, respectively.

\section{Discussion}

Our study resolved and confirmed taxonomic placement of five sclerotial pathogenic species among genera of Ascomycota and Basidiomycota. Results from our study suggest that morphological characters such as mycelia coloration, hyphal diameter, shape and size of sclerotia are insufficient to characterize sclerotial fungi. Andersen [10] and Stalpers and Andersen [11] suggested that morphological characteristics feature differ considerably with temperature, light and composition of the medium in many isolates of sclerotial fungi and often have a dissimilar appearance when grow on different nutrient medium. Coupled with DNA sequences data with morphological characters is a useful tool in delineating species as also advocated [12].

Nuclear ribosomal DNA sequences revealed that the $R$. solani, $R$. bataticola, M. phaseolina, S. rolfsii and $\mathrm{S}$. sclerotiorum represent two distinct lineages. The inferred rDNA phylogeny supports the two lineage hypothesis. Cladistic analysis of ITS region with 5.8S gene confirmed that $R$. solani and $R$. bataticola are not monophyletic genera. Our results support the findings of other researchers based on an examination of septal pore, teleomorph characters and sequence data [13-17].

Cladistic analysis also revealed that $R$. bataticola and $M$. phaseolina showed the maximum similarity based on ITS-5.8S gene sequences which support the relationships among them but sequences data revealed the existence of four nucleotide differences in the entire ITS1-5.8S-ITS2 gene sequences that showed some degree of variation which help in distinguished between $R$. bataticola and $M$. phaseolina and supports their independent evolutionary lineage. Edel et al. [18] identified Fusarium spp. on the basis of sequence variation in $28 \mathrm{~S}$ rRNA gene. $R$. solani and $S$. rolfsii are known to have teleomorph stages but $R$. bataticola and $M$. phaseolina have not been placed with teleomorph connection due to not availability of identical gene sequences in the NCBI database. Carbone and Kohn [19] demonstrated the confirmations of anamorphteleomorph connection by comparative sequences analysis of amplified products of Sclerotinia and Sclerotium which showed $98 \%$ sequences homology in the ITS region of rDNA. Similarly, Kuhls et al. [20] established the connection between Trichoderma anamorph and Hypocrea teleomorphs which supported by $100 \%$ identify in ITS1 and ITS2 sequences. Egger and Sigler [21] investigated anamorph Scytalidium vaccinii with teleomorph Hymenoscypthes ericae and found 1.2-3.55\% divergence in the ITS1 and ITS2 regions and concluded from these data and morphological observations that $S$. vaccinii and $H$. ericae are anamorph and teleomorph of a single taxon.

Study provided phylogenetic relationship of sclerotial species as a whole and phylogenetic placement for each individual species. This information is critical in assessing disease management strategies, such as fungicide application. Some classes of fungicides have mode of action that are specific for either Basidiomycota or Ascomycota [6]. For instance Carboxin is active on Basidiomycetes whereas Fenhexamid is active only on Ascomycetes. Therefore, results help to choose appropriate fungicide which improves their ability to manage economically important disease caused by these phytopathogens.

\section{Acknowledgements}

First author is thankful to The Head, Department of Botany, J.N.V. University Jodhpur for research support and CSIR (New Delhi) for financial assistance under the Pool Scheme for SRAs

\section{References}

[1] Singh S.K., Nene Y.L. and Reddy M.V. (1990) Plant Disease, 74(10), 612-614.

[2] Vilgalys R. and Cubeta M. A. (1994) Ann. Rev. Phytopathol., 32, 135-155.

[3] Boland G. J. and Hall R. (1994) Can. J. Plant Pathol., 16, 93-100.

[4] Okabe I. and Matsumoto N. (2003) Mycol. Res., 107, 164-168.

[5] Xu Z., Harrington T. C., Gleason M. L. and Batzer J.C. (2010) Mycologia, 102, 337-346.

[6] McGrath M.T. (2004) What are fungicides? The plant health instructor 22 October 2011. DOI: $\quad 10 . \quad 1094 / \mathrm{PHI}-\mathrm{I}-2004-0825-01$ (http://www.apsnet.org/education/IntroPlantPat $\mathrm{h} /$ Topics/fungicides/default.htm).

[7] Babu B. K., Saxena A. K., Srivastava A. K. and Arora D. K. (2007) Mycologia, 99, 797-803.

[8] Bruns T.D., White T. J. and Taylor J. W. (1991) Ann. Rev. Ecol. Syst., 22, 525-564.

[9] White T. J., Bruns T. D., Lee S. and Taylor J. W. (1990) In: Innis M. A., Gelfand D. H., Sninsky J. J., White T. J., (eds.) PCR protocols, a Guide to methods and applications Academic press, New York pp 315- 322.

[10] Andersen T. F. (1990) Mycotaxon, 37, 25-46.

[11] Stalpers J.A. and Andersen T.F. (1996) In: Sneth B., Jabaji-Here S., Neate S., Dijst G. (eds.) Rhizoctonia species: Taxonomy, Molecular Biology, Ecology, Pathology and Disease control. Kluwer Academic Publishers, Dordecht pp 49-66.

[12] Harrington T.C. and Rizzo D.M. (1999) In: Worrall J.J. (ed.) Structure and dynamics of fungal population. Dordrecht, the Netherlands: Kluwer Academic Press. pp 43-70.

[13] Tu C.C. and Kimbrough J. W. (1978). Bot. Gaz., 139, 454-466.

[14] Andersen T.F. (1996) Mycol. Res., 100, 11171128.

[15] Moore R. T. (1996) In: Sneh B., Jabaji- Here S., Neate S., Disjst G. (eds.) Rhizoctonia Species: Taxonomy, Molecular Biology, 
Ecology, Pathology and Disease control. Kluwer Academic Publishers Dordrecht, The Netherlands pp 13-35.

[16] Gonzalez D. Carling D. E., Kunninaga S, Vilgalys R. and Cubeta M. A. (2001) Mycologia, 93, 1138-1150.

[17] Gonzalez D., Portal Onco M.A. and Susan V.R. (2006) Spanish J. Agr. Res., 4, 55-79.
[18] Edel V., Steinberg C, Gautheron N. and Alabouvette C. (2000) Mycol. Res., 104, 518526.

[19] Carbone I. and Kohn L.M. (1993) Mycologia, 85, 415-427.

[20] Kuhls K., Lieckfeldt E., Samuels G.J., Mayer W., Kubicek C. P. and Borner T. (1997) Mycologia, 89, 442-460.

[21] Egger K. N. and Sigler L. (1993) Mycologia, 85, 219-230.

Table 1- Cultural characters and Nucleotide base pair lengths of internal transcribed spacer region encompassing 5.8S ribosomal DNA gene

\begin{tabular}{|c|c|c|c|c|c|c|c|c|}
\hline Group & $\begin{array}{l}\text { Isolates } \\
\text { (No.) }\end{array}$ & Species & $\begin{array}{l}\text { Cultural characteristics of Sclerotial } \\
\text { fungi }\end{array}$ & $\begin{array}{l}\text { ITS- } \\
1 \\
\text { (bp) }\end{array}$ & $\begin{array}{l}5.8 S \\
\text { gene } \\
\text { (bp) }\end{array}$ & $\begin{array}{l}\text { ITS- } \\
2 \\
\text { (bp) }\end{array}$ & $\begin{array}{l}\text { Total } \\
\text { (bp) }\end{array}$ & $\begin{array}{l}\text { Gen } \\
\text { accession } \\
\text { number }\end{array}$ \\
\hline I & 12 & $\begin{array}{l}\text { Rhizoctonia } \\
\text { bataticola }\end{array}$ & $\begin{array}{l}\text { Colonies on PDA media brown to black. } \\
\text { Mycelium brown to pale brown in color, } \\
\text { branching more or less at right angles. } \\
\text { Sclerotia black, minute smooth variable } \\
\text { in shape, globose, oval, oblong, } \\
\text { elliptical, curved or even forked, size } 25- \\
150 \mu \mathrm{m}\end{array}$ & 181 & 158 & 152 & 491 & JN093298 \\
\hline II & 9 & $\begin{array}{l}\text { Macrophomina } \\
\text { phaseolina }\end{array}$ & $\begin{array}{l}\text { Colonies on PDA media light brown to } \\
\text { brown in color. Mycelium long, septate, } \\
\text { branched. Sclerotia black, smooth, hard, } \\
\text { thick walled, size } 100-300 \mu \mathrm{m}\end{array}$ & 183 & 157 & 151 & 491 & JN093297 \\
\hline III & 7 & $\begin{array}{l}\text { Rhizoctonia } \\
\text { solani } \\
\text { (teleomorph = } \\
\text { Thanatephorus } \\
\text { cucumeris) }\end{array}$ & $\begin{array}{l}\text { Colonies on PDA media first colorless, } \\
\text { rapidly becoming brown. Mycelium } \\
\text { brown to deep brown in color, long } \\
\text { branched. Branches arise near distal } \\
\text { end of cell constricted at point of origin } \\
\text { and septate shortly above, branching } \\
\text { approaches } 90 \text { degree. Sclerotia brown } \\
\text { to deep brown in color, irregular in shape } \\
\text { and size, scattered over the colony } \\
\text { surface, size } 25-100 \mu \mathrm{m}\end{array}$ & 219 & 155 & 252 & 626 & JN093296 \\
\hline IV & 5 & $\begin{array}{l}\text { Sclerotium } \\
\text { rolfsii } \\
\text { (teleomorph } \\
=\text { Athelia rolfsii) }\end{array}$ & $\begin{array}{l}\text { Colonies on PDA media whit in color. } \\
\text { Hyphae irregular in thickness, septate } \\
\text { and hyaline, Sclerotia develop on colony } \\
\text { surface. Sclerotia smooth, globose, } \\
\text { brown in colour, size of sclerotia } 1-2 \\
\mathrm{~mm} \text {. }\end{array}$ & 205 & 154 & 232 & 591 & JN093299 \\
\hline $\mathrm{V}$ & 5 & $\begin{array}{l}\text { Sclerotinia } \\
\text { sclerotiorum }\end{array}$ & $\begin{array}{l}\text { Colonies on PDA media white of soft } \\
\text { white in color. Mycelium white, long, } \\
\text { narrow branched, septate. Single } \\
\text { sclerotium develops on colony surface } \\
\text { mainly near edge of Petri-dish after rapid } \\
\text { hyphal expansion has ceased black } \\
\text { randed or elongated up to } 1 \mathrm{~cm} \text { across } \\
\text { with smooth or shallowly pitted surface. }\end{array}$ & 148 & 158 & 146 & 452 & JN093300 \\
\hline
\end{tabular}




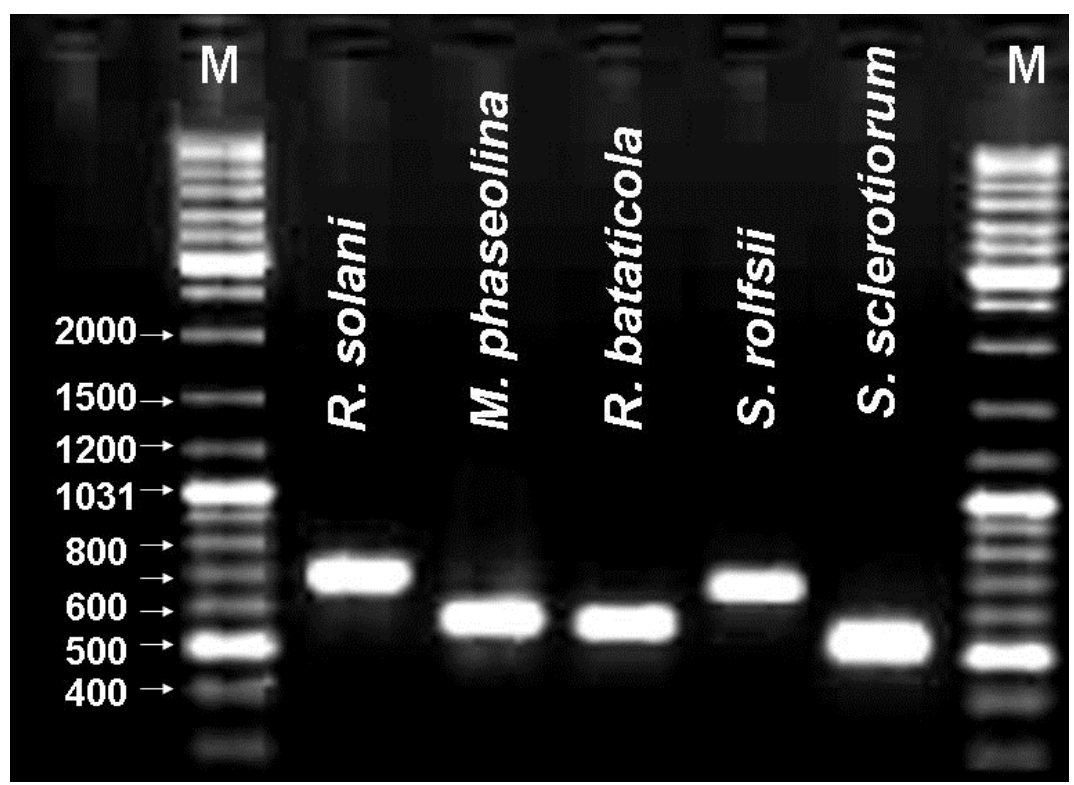

Fig. 1- ITS profiles of 5 Sclerotial phytopathogens

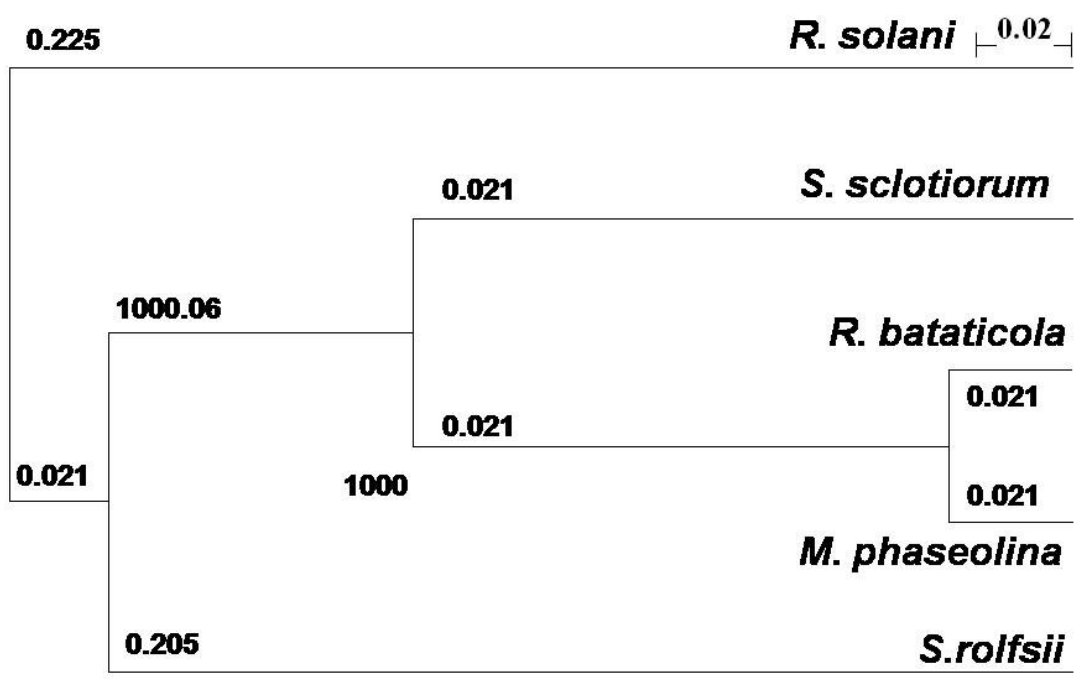

Fig. 2- Phylogram based on multiple sequence alignment of Sclerotial phytopathogens using tree view software 